Tropical Journal of Pharmaceutical Research December 2020; 19 (12): 2667-2675

ISSN: $1596-5996$ (print); 1596-9827 (electronic)

(C) Pharmacotherapy Group, Faculty of Pharmacy, University of Benin, Benin City, 300001 Nigeria

Available online at http://www.tjpr.org

Original Research Article

http://dx.doi.org/10.4314/tjpr.v19i12.27

\title{
Pharmacognostic, phytochemical, biological and spectroscopic analyses of Capparis decidua (Forsk.) Edgew root and stem bark
}

\author{
Muhammad Asif Wazir'1, Muhammad Iqbal Azhar'1, Zafar Alam Mehmood', \\ Muhammad Imran Qadir ${ }^{2}$, M Younis Khan ${ }^{3}$, Faheem Ahmad Siddique ${ }^{4}$, Talal \\ Shaheer $^{5}$, Waqar Hussain ${ }^{6}$, Khizar Abbas ${ }^{7 *}$ \\ ${ }^{1}$ Department of Pharmacognosy, Faculty of Pharmacy and Pharmaceutical Sciences, University of Karachi, Karachi, ${ }^{2}$ Institute \\ of Molecular Biology \& Biotechnology, Bahauddin Zakariya University, Multan, Pakistan, ${ }^{3}$ Department of Pharmacy, The Islamia \\ University of Bahawalpur, Bahawalpur, ${ }^{4}$ Department of Pharmacy, University of Central Punjab Lahore, ${ }^{5}$ School of Pharmacy, \\ Xi'an Jiaotong University, Xi'an, Shaanxi, China, ${ }^{6}$ Department of Pharmaceutical Chemistry, ${ }^{7}$ Department of Pharmacognosy, \\ Faculty of Pharmacy, Bahauddin Zakariya University, Multan, Pakistan
}

*For correspondence: Email: khizarabbas@bzu.edu.pk; Tel: +92-3228832872

Sent for review: 5 March 2020

Revised accepted: 15 November 2020

\begin{abstract}
Purpose: To investigate the pharmacognostic, phytochemical, biological and spectroscopic analyses of Capparis decidua (Forsk.) Edgew root and stem bark.

Methods: Plant material (root and stem bark) was collected, authenticated, shade-dried and extracted by maceration using methanol as a solvent separately. Powder microscopy was performed using a binocular microscope. Fluorescence, physico-chemical analysis and phytochemical screening for the presence of secondary metabolites were performed using standard methods. Brine shrimp lethality bioassay was carried out using Artemia salina bioassay, while enzymatic modulatory study was performed by a-amylase inhibition assay. Microscopic analysis was carried out with scanning electron microscopy. Spectroscopic analysis was performed by Fourier transform infrared spectroscopy (FTIR).

Results: Powder microscopy showed the presence of different cellular structures. Various colors were observed under ultraviolet (UV) and ordinary light when treated with different reagents. Phytochemical screening revealed the presence of alkaloids, tannins, saponins and flavonoids but phenol and cardiac glycosides were absent from both extracts. The root bark of the plant showed significant brine shrimp lethality activity.

Conclusion: Capparis decidua (Forsk.) Edgew root and stem bark contain a variety of bioactive compounds that have medicinal and therapeutic potentials. Therefore, further investigations are required to elucidate their pharmacological properties.
\end{abstract}

Keywords: Capparis decidua (Forsk.) Edgew, Phytochemical, Spectroscopy, a-Amylase

This is an Open Access article that uses a fund-ing model which does not charge readers or their institutions for access and distributed under the terms of the Creative Commons Attribution License (http://creativecommons.org/licenses/by/4.0) and the Budapest Open Access Initiative (http://www.budapestopenaccessinitiative.org/read), which permit unrestricted use, distribution, and reproduction in any medium, provided the original work is properly credited.

Tropical Journal of Pharmaceutical Research is indexed by Science Citation Index (SciSearch), Scopus, International Pharmaceutical Abstract, Chemical Abstracts, Embase, Index Copernicus, EBSCO, African Index Medicus, JournalSeek, Journal Citation Reports/Science Edition, Directory of Open Access Journals (DOAJ), African Journal Online, Bioline International, Open-J-Gate and Pharmacy Abstracts

\section{INTRODUCTION}

Majority of the synthetic drugs used at the present time for analgesic and antinociceptive effect have many side and toxic effects. Utilization of plant-based products is increasing because $80-90 \%$ rural population of developing countries use herbal products for prevention, 
diagnosis, treatment and cure of diseases. For these reasons, the use of plant-based products is increasing day by day as 80 - $90 \%$ of the world's population using herbal products for diagnosis, prevention, treatment and cure of many problems. Plants still account for a large untapped resource of structurally novel active compounds that might serve as lead source for the development of growth of synthetic novel drugs [1].

The genus Capparis comprises 250 species which include shrubs, trees and woody climbers. Capparis decidua (Forsk.) Edgew commonly known as Karer, Karukaril, or Karel, is a densely branching shrub or a small tree of the Thar Desert of Pakistan, also found in Central America, South American countries, southeast United States and southeast China [2]. Alkaloids, terpenoids, glycosides, fatty acids $\beta$-sitosterol [3], capparidisine [4], capparasinine [5], isocodonocarpine, codonocarpine, [6], rutin and stachydrine are present in different parts of the plant [7]. The plant possesses antihypercholesterolemic [8], anti-inflammatory, antidiabetic [9], antiplaque, antihypertensive [7], antimicrobial, anthelmintic, analgesic and purgative properties [10]. Due to their versatile medicinal properties and pharmacological actions of Capparis decidua (Forsk.) Edgew, the present research work was planned to standardize the different parts of plant using spectroscopic.

\section{EXPERIMENTAL}

\section{Collection and authentication}

Capparis decidua (Forsk.) Edgew root and stem bark was collected from the vicinity of District Muzaffar Garh (Punjab) in 2018. The plant parts such as root and stem bark were cleaned, identified and authenticated by Dr Zafar Ullah Zaffar, Taxonomist, Department of Botany Bahauddin Zakariya University Multan with a voucher specimen (no. Stewart F. W. Pak. 293) and the specimen deposited in herbarium of Department of Pure and Applied Biology, Bahauddin Zakariya University, Multan, Pakistan.

\section{Preparation of extract}

Powdered root bark and stem bark of the plant were made after shade drying for 30 days at room temperature separately by using mechanical grinder. These powders were preserved in the air tight container at cool place. Then $500 \mathrm{~g}$ of each part was soaked separately in $1.0 \mathrm{~L}$ of distilled ethanol for 7 days in ambercolored glass bottles. The solvent was filtered through Whatman's filter paper No 1. The filtrate obtained was concentrated using rotary vacuum evaporator (Rotavapor-R-200 Buchi) at 40 - 50 ${ }^{\circ} \mathrm{C}$. The Capparis decidua (Forsk.) Edgew ethanolic extract of root bark (CDERB) and ethanolic extract of (CDESB), were weighed and stored inat $4^{\circ} \mathrm{C}$ in biomedical freezer (Sanyo Biomedical freezer, model MDF- U333, Japan).

\section{Macroscopic analysis}

Standard protocols were used for macroscopic studies to analyse the size, colour, taste, feature, texture and shape of Capparis decidua (Forsk.) Edgew. Root and stem bark [11].

\section{Microscopic and histochemical studies}

Microscopic studies of Capparis decidua (Forsk.) Edgew root and stem bark was performed according to the standard protocol established by World Health Organization [12].

\section{Fluorescence analysis}

Fine powder of root and stem bark (1 $\mathrm{g}$ each) was placed in a test tube and freshly prepared various reagents were added in different test tubes separately. It was shaken gently and placed for half an hour. Color of each test tube was observed in daylight, then placed these test tubes in UV lamp and observed the change in color at $254 \mathrm{~nm}$ and $365 \mathrm{~nm}$ wavelength [13].

\section{Physicochemical analysis}

Physico-chemical analysis was performed according to the protocol already established protocol.

\section{Loss on drying}

Powdered of root and stem bark $(2.0 \mathrm{~g})$ of each was weighed and placed in clean dried china dish. China dish with powdered material was weighed and dried in oven at $105^{\circ} \mathrm{C}$. Then heat it up to the constant weight until difference of not more than $0.5 \%$ is achieved between two successive readings on drying. The result was calculated by following formula:

$\%$ LOD $=$ Weight of the sample after drying/ weight of the sample before drying $\times 100$ [13].

\section{Foaming index}

Powdered root and stem bark $(1.0 \mathrm{gm})$ each were taken in a separate conical flask with 100 $\mathrm{mL}$ of water and was heated for 30 minutes. The mixture was cooled, filtered and volume was 
made up to $100 \mathrm{~mL}$. After that 10 test tubes were taken and 1 to $10 \mathrm{~mL}$ of filtrate was added in each test tube in a gradually increasing sequence. The volume was adjusted up to $10 \mathrm{~mL}$ and the test tubes were shaken for 15 second and kept in a rack for 15 minutes without any disturbance after that height of froth was measured [13].

\section{Swelling index}

Powdered sample $(2.0 \mathrm{~g})$ of each plant part was taken in $25 \mathrm{~mL}$ stoppered flask and was shaken for $1.0 \mathrm{hr}$. The sample was kept for three hours and volume was measured occupied by the sample [13].

\section{Phytochemical screening}

Phytochemical screening was performed according to the standard described procedures [14].

The preliminary phytochemical screening of the methanol extracts of Capparis decidua (Forsk.) Edgew root and stem bark were performed by adopting the standard procedures.

\section{Wagner's test}

Methanolic extract of root and stem bark $(2 \mathrm{~mL})$ were taken in test tubes separately. $1 \mathrm{~mL}$ freshly prepared wagner's reagent was added in both the test tubes. The reddish-brown precipitates appeared which indicates the presence of alkaloid.

\section{Dragendorff's test}

Methanolic extract of root and stem bark $(2 \mathrm{~mL})$ were taken in a test tube separately. Add one 1 $\mathrm{mL}$ of freshly prepared Dragendorff's reagent in each test tube. Appearance of the white precipitates indicated the presence of alkaloid.

\section{Mayer's test}

Methanolic extract of root and stem bark (2 $\mathrm{mL})$ were taken in a test tube separately. Add $1 \mathrm{~mL}$ of Mayer's reagent in both test tubes. The formation of creamy precipitates indicated the presence of alkaloid.

\section{Hager's test}

Methanolic extract of root and stem bark $(2 \mathrm{~mL})$ were taken in a test tube separately. Add $1 \mathrm{~mL}$ of Hager's reagent in both test tubes. The formation of yellow precipitates indicated the presence of alkaloid.

\section{Tannic acid test}

Methanolic extract of root and stem bark $(2 \mathrm{~mL})$ were taken in a test tube separately. Add $1 \mathrm{~mL}$ of tannic acid solution in both test tubes. The formation of buff color precipitates indicated the presence of alkaloid.

\section{Killar Killani test}

Methanolic extract of root and stem bark $(2 \mathrm{~mL})$ were taken in a test tube separately. $2 \mathrm{~mL}$ glacial acetic acid and 2 drops of $\mathrm{FeCl}_{3}$ solution were added followed by the addition of conc. $\mathrm{H}_{2} \mathrm{SO}_{4}$ along the walls of the test tube.

A brown colored ring appearing at the interface of the test tube confirms the presence of cardiac glycoside.

\section{Legal test}

Methanolic extract of root and stem bark (2 mL) were taken in the test tube separately and dissolved in pyridine. Sodium nitroprusside solution was added to it to make it alkaline. Appearance of pink or red color indicates the presence of cardiac glycoside.

\section{Water test}

Methanolic extract of root and stem bark $(3 \mathrm{~mL})$ were taken in the test tube separately. Add $5 \mathrm{~mL}$ distilled water in both the test tubes and shake them vigorously. Froth formation confirms the presence of saponins.

\section{Blood test}

Methanolic extract of root and stem bark $(1 \mathrm{~mL})$ were taken in the test tube separately, to which were added 2 - 3 drops of blood. Hemolysis of blood confirmed the presence of saponins.

\section{Ferric chloride test}

Methanolic extract of root and stem bark $(1 \mathrm{~mL})$ were taken in the test tube separately, to which were added 4 - 5 drops of $\mathrm{FeCl}_{3}$ solution. Appearance of a blackish precipitate confirmed the presence of tannins.

\section{Lead acetate test}

Methanolic extract of root and stem bark $(2 \mathrm{~mL})$ were taken in the test tube separately. Add 2 - 3 drops of $1 \%$ lead acetate. Yellowish precipitate confirms the presence of tannins. 


\section{Gelatin test}

Methanolic extract of root and stem bark $(2 \mathrm{~mL})$ were taken in the test tube separately and added $1 \mathrm{~mL}$ of $1 \%$ gelatin solution. White precipitate indicated the presence of tannins.

\section{Lead acetate test}

Methanolic extract of root and stem bark $(2 \mathrm{~mL})$ were taken in the test tube separately and added $1 \mathrm{~mL}$ of basic lead acetate. Reddish-brown precipitate indicated the presence of flavonoids.

\section{$\mathrm{FeCl}_{3}$ test for flavonoids}

Methanolic extract of root and stem bark $(2 \mathrm{~mL})$ were taken in the test tube separately and mixed few drops of $\mathrm{FeCl}_{3}$. Blackish precipitate indicated the presence of flavonoids.

\section{Alkaline solution test}

Methanolic extract of root and stem bark $(2 \mathrm{~mL})$ were taken in the test tube separately and added $1 \mathrm{~mL}$ of $\mathrm{NaOH}$. Yellow to red precipitate indicated the presence of flavonoids.

\section{$\mathrm{H}_{2} \mathrm{SO}_{4}$ test}

Methanolic extract of root and stem bark $(2 \mathrm{~mL})$ were taken in the test tube separately and added $2 \mathrm{~mL}$ of concentrated $\mathrm{H}_{2} \mathrm{SO}_{4}$. Appearance of yellow to orange color indicated the presence of flavonoids.

\section{Stain test}

Methanolic extract of root and stem bark (100 mg) were pressed between two folds of filter paper. Stains left on paper indicated the presence of fixed oils.

\section{Saponification test}

Methanolic extract of root and stem bark $(2 \mathrm{~mL})$ were taken in the test tube separately and added $2 \mathrm{~mL}$ of $\mathrm{NaOH}$. Saponification indicated the presence of lipids.

\section{Ferric chloride test for phenols}

The methanol extract of root and stem bark (2 $\mathrm{mL}$ ) were taken in the test tube separately and added $1 \mathrm{~mL}$ of $\mathrm{FeCl}_{3}$ solution.

Appearance of intense blue color indicated presence of phenol in test solution.
Hydrochloric acid $(\mathrm{HCl})$ test

Methanolic extract of root and stem bark $(2 \mathrm{~mL})$ were taken in the test tube separately and added $1 \mathrm{~mL} \mathrm{HCl}$. Appearance of pink color indicated the presence of resins.

\section{Ferric chloride test for resin}

Methanolic extract of root and stem bark $(2 \mathrm{~mL})$ were taken in the test tube separately and added $1 \mathrm{~mL} \mathrm{FeCl} 3$ solution. Appearance of intense green color indicated the presence of phenol in test solution.

\section{Test for quinones}

Methanolic extract of root and stem bark (2 mL) were taken in test tube separately to which was added $2 \mathrm{~mL} \mathrm{HCl}$. Appearance of yellow color indicated the presence of quinones.

\section{Brine shrimp lethality assay}

The sample (ethanolic extract of root and stem bark, $20 \mathrm{mg}$ of each) was dissolved separately in $2 \mathrm{~mL}$ of solvent and concentration was made 10 , 100 and $1000 \mu \mathrm{g} / \mathrm{mL}$ respectively and kept them overnight for drying, then hatched 10 larvae/vials was placed using pipette.

Final volume was made up to $5 \mathrm{~mL}$ with sea water and incubated at $25-27{ }^{\circ} \mathrm{C}$ for one day under light, after that number of survivors in each vial was calculated. The experiment was performed in triplicate. Etoposide was used as a standard drug and tested as a positive control. Finney computer program was used to analyze the data for the determination of LD 50 with $95 \%$ confidence intervals $[15,16]$.

\section{Enzymatic activity}

Plant extract (root and stem bark) of different concentrations was incubated along with 50 $\mu \mathrm{g} / \mathrm{mL}$ of porcine pancreatic alpha amylase at 37 ${ }^{\circ} \mathrm{C}$ for $10 \mathrm{~min}$. After incubation, substrate solution (1\% starch) was added in each test tube. Alpha amylase without extracts was used as control for starch. The absorbance was then estimated using DNSA assay at $540 \mathrm{~nm}$. The inhibitory activity was calculated using Eq 1 [17].

Inhibition $(\%)=\{(\mathrm{Ac}-\mathrm{At}) / \mathrm{Ac}\} 100$

Where Ac and At are the absorbance of control and test samples, respectively. 


\section{Microscopic analysis}

Scanning electron microscope was used to carry out surface morphology of root and stem bark powder. Sample powder was placed in the sample chamber of SEM and scaaning was performed at a different magnification ranging from 1000 to 4000 at 10,20 and $40 \mu \mathrm{m}$.

\section{Spectroscopic analysis}

Spectroscopic analysis was performed by using Fourier transform infrared spectroscopy (FTIR) (Bruker Tensor series 27, Germany) with ATR technology. The infrared spectra of extract was recorded from 500 to $4000 \mathrm{~cm}^{-1}$ wavenumber.

\section{RESULTS}

Macroscopic analysis shows that root bark was light brown in colour, with smooth texture and tough fracture, while the stem bark was whitish grey in colour, with rough texture and fibrous fracture as shown in Table 1.

Table 1: Macroscopic characters of Capparis decidua (Forsk.) Edgew

\begin{tabular}{lll}
\hline Characteristic & Root bark & Stem bark \\
\hline Color & Brown & Whitish-grey \\
Odor & Odorless & Odorless \\
Taste & Slightly bitter & Tasteless \\
Fracture & Tough & Fibrous \\
Texture & Smooth & Rough \\
\hline
\end{tabular}

Physicochemical analysis results are presented in Table 2 which indicate that total ash of root bark was $0.45 \mathrm{~g}$, acid insoluble ash was $0.025 \mathrm{~g}$ and water-soluble ash was $0.045 \mathrm{~g}$ whereas stem bark total ash value was 0.045 , acid insoluble ash was $0.005 \mathrm{~g}$ and water-soluble ash was $0.01 \mathrm{~g}$.

Table 2: Physicochemical parameters of Capparis decidua (Forsk.) Edgew root and stem bark

\begin{tabular}{lcc}
\hline Parameter & Root bark & Stem bark \\
\hline Total ash $(\mathrm{g})$ & 0.45 & 0.045 \\
Acid insoluble ash $(\mathrm{g})$ & 0.025 & 0.005 \\
Water soluble ash $(\mathrm{g})$ & 0.045 & 0.01 \\
Swelling index $(\mathrm{mL})$ & 7.5 & 5.5 \\
Foaming index & $<100$ & $<100$ \\
Loss on drying $(\%)$ & $0.50 \pm 0.01$ & $0.7 \pm 0.01$ \\
\hline
\end{tabular}

The results of fluorescence analysis of root and stem bark powder showed characteristic coloration under visible and UV light upon treatment with different chemical reagents (Table $3)$.

Powder microscopy of root bark showed the presence of different structures like calcium oxalate crystal, fibers, parenchyma and starch granules, while stem bark showed the parenchyma, starch, sclereoids and nonglandular trichome, as indicated in Figure 1 and Figure 2, respectively.

The phytochemical investigation of the methanolic extract of root and stem bark of Capparis decidua (Forsk.) Edgew showed the presence of alkaloids, resin, tannins, flavonoids, saponins and fats while cardiac glycosides and phenols were absent in both extracts (Table 4).

The result of the Brine Shrimp lethality of the methanolic extract of Capparis decidua is given in Table 5. The extracts did not show any enxymatic activity (Table 6)

Table 3: Fluorescence analysis of Capparis decidua (Forsk. Edgew) root bark and stem bark

\begin{tabular}{lllll}
\hline \multirow{2}{*}{ Powdered drug } & \multicolumn{2}{c}{ Visible/daylight } & \multicolumn{2}{c}{ UV Light } \\
\cline { 2 - 5 } & Root bark & Stem bark & Root bark & Stem Bark \\
\hline Powder + water & Brown & Light brown & White & Turquoise \\
Powder+ conc. $\mathrm{HNO}_{3}$ & Light orange & Orange & Blackish brown & Brown \\
Powder + chloroform & Light brown & Light brown & Light brown & White \\
Powder+ acetic acid & Brown & Light brown & Light green & Turquoise \\
Powder+ conc. $\mathrm{H}_{2} \mathrm{SO}_{4}$ & Black & Green & Light green & Green \\
Powder + methanol & Brown & Light green & White & white \\
Powder + lodine & Light brown & Light brown & Light green & Turquoise \\
Powder + glycerin & Brown & Light brown & White green & Turquoise \\
Powder $+5 \% \mathrm{FeCl}$ & Yellowish green & Blood red & Blackish green & Black \\
Powder $+1 \% \mathrm{NaOH}$ & Dark brown & Brown & Light Cream & Light green \\
Powder+glacial acetic acid & Light brown & Light brown & Cream & Turquoise \\
Powder $+\mathrm{Picric}_{\text {acid }}$ & Brown & Yellow & Brown & Brown \\
Powder $+\mathrm{NH}_{4} \mathrm{OH}$ & Brown & Dark brown & Turquoise & White \\
Powder + acetonitryl & Mud Brown & White & White & light pink \\
Powder + Diethyl ether & Light brown & Light brown & White & Turquoise \\
\hline
\end{tabular}


The scan of the electron microscopy of the plant root and stem bark is provided in Figure 3 while the FTIRscan are shown in Figure 4

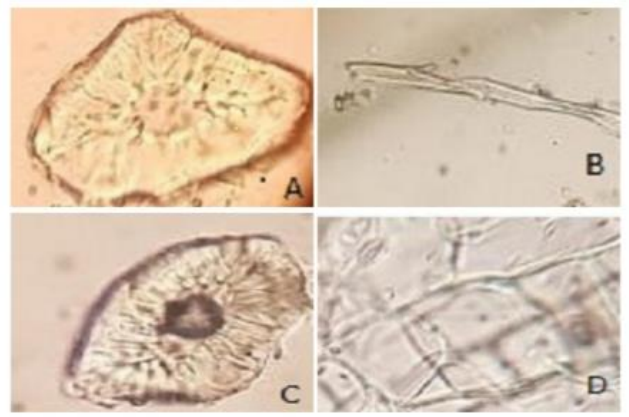

Figure 1: Powder microscopy of root bark Capparis decidua (A) calcium oxalate crystal (B) Fibers (C) Parenchyma (D) Starch

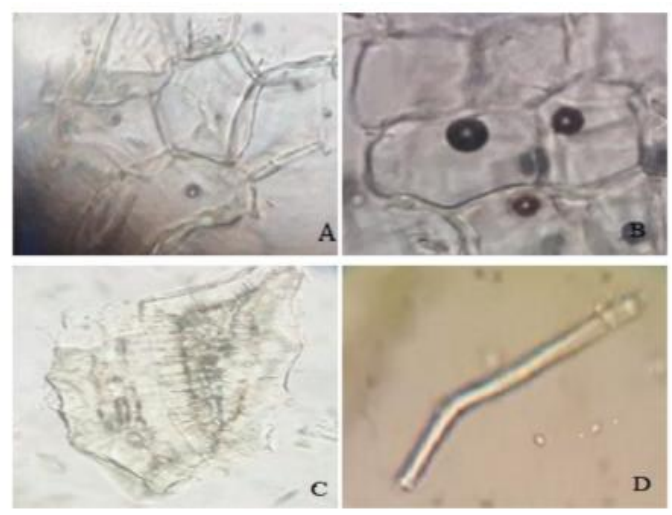

Figure 2: Powder microscopy of Capparis decidua (A) parenchyma, (B) starch (C) Sclereids (D) nonglandular trichome

Table 4: Phytochemical profile of Capparis decidua (Forsk.) Edgew root and stem bark

\begin{tabular}{|c|c|c|c|}
\hline Test & Reagent & Root bark & Stem bark \\
\hline \multirow{4}{*}{ Alkaloids } & Dragendorff & +++ & +++ \\
\hline & Wagner & +++ & +++ \\
\hline & Mayer & ++ & ++ \\
\hline & Hager & ++ & ++ \\
\hline Resin & $\mathrm{CuSO}_{4}$ & ++ & ++ \\
\hline \multirow[t]{2}{*}{ Cardiac glycoside } & Killer Killani & - & - \\
\hline & Lead acetate & ++ & ++ \\
\hline \multirow[t]{3}{*}{ Tannins } & $\mathrm{FeCl}_{3}$ & ++ & ++ \\
\hline & Gelatin & ++ & ++ \\
\hline & Lead acetate & ++ & ++ \\
\hline \multirow[t]{2}{*}{ Flavonoids } & $\mathrm{FeCl}_{3}$ & ++ & ++ \\
\hline & $\mathrm{NaOH}$ & ++ & ++ \\
\hline Phenols & $\mathrm{FeCl}_{3}$ & - & - \\
\hline Fats & Saponification & + & + \\
\hline Quinones & $\mathrm{KOH}$ & - & - \\
\hline Saponins & Dist. water & ++ & ++ \\
\hline
\end{tabular}

Table 5: Brine Shrimp lethality of the methanolic extract of Capparis decidua (Forsk.) Edgew root and stem bark

\begin{tabular}{|c|c|c|c|c|c|c|}
\hline \multirow{2}{*}{ Dose $(\mu \mathrm{g} / \mathrm{mL})$} & \multirow{2}{*}{$\begin{array}{c}\text { No. of } \\
\text { shrimps }\end{array}$} & \multicolumn{2}{|c|}{ No. of survivors } & \multicolumn{2}{|c|}{ Mortality (\%) } & \multirow{2}{*}{$\begin{array}{c}\text { Mortality } \\
(\%)\end{array}$} \\
\hline & & Root bark & Stem bark & Root bark & Stem bark & \\
\hline 10 & 30 & 27 & 21 & 10 & 30 & \\
\hline 100 & 30 & 13 & 20 & 56.66 & 33.33 & 46.66 \\
\hline 1000 & 30 & 04 & 19 & 86.66 & 36.66 & \\
\hline
\end{tabular}

Table 6: Enzymatic activity of methanolic extract of Capparis decidua (Forsk.) Edgew root and stem bark

\begin{tabular}{lccl}
\hline Part used & Activity & $\begin{array}{c}\text { Standard } \\
\text { drug }\end{array}$ & $\begin{array}{l}\text { Standard } \\
\text { enzyme }\end{array}$ \\
\hline Root bark & No activity & Acarbose & a-Amylase \\
Stem bark & No activity & & \\
\hline
\end{tabular}

\section{DISCUSSION}

Standardization of medicinal plants and their extract have great importance because quality control plays a major role in the safety and efficacy of drug. It starts at the initial stages from the production of quality materials because according to World Health Organization (WHO), before testing any herbs for the corresponding pharmacological activity, it needs to be standardized by set of guidelines for establishing identity and purity of the drug materials [18]. Ash 


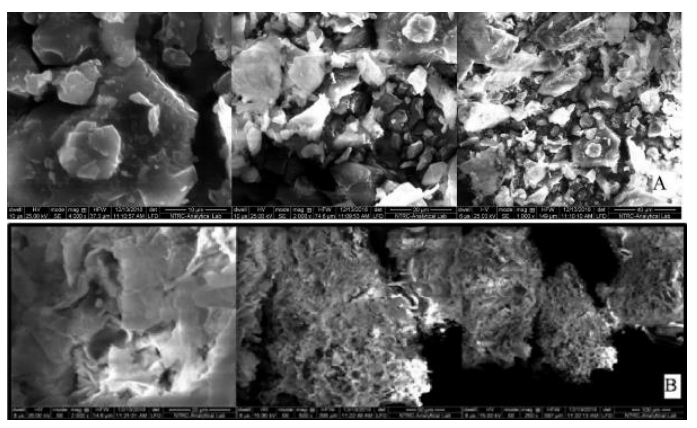

Figure 3: Scanning electron microscopy of Capparis decidua (Forsk.) Edgew (A) root bark (B) stem bark
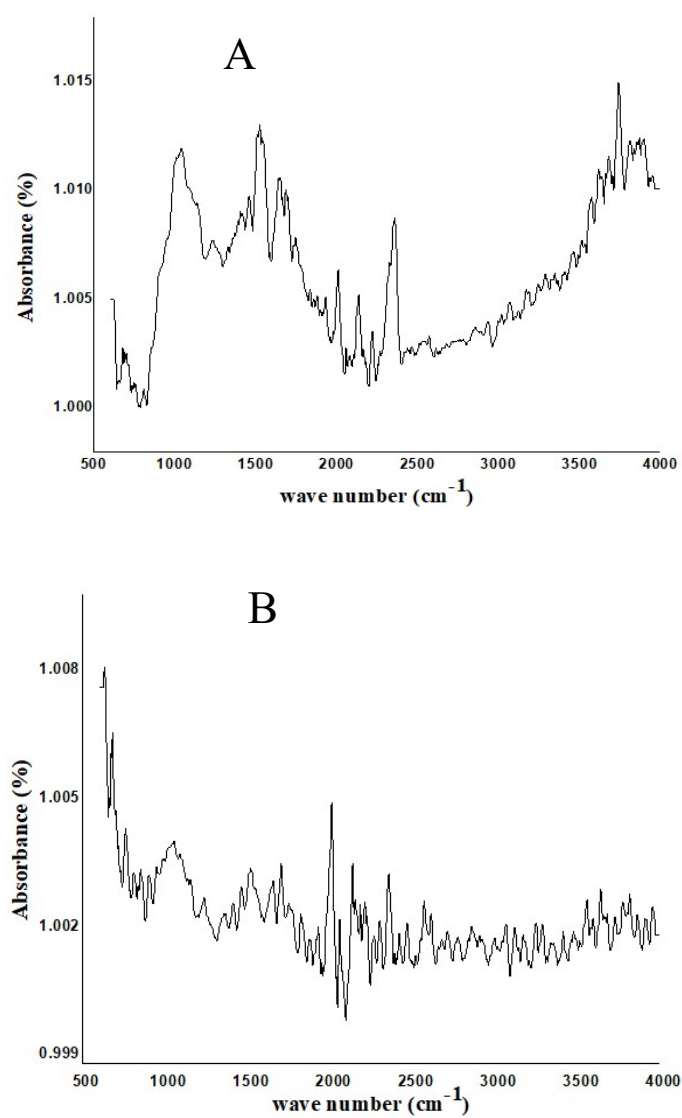

Figure 4: FTIR of Capparis decidua (Forsk.) Edgew root bark $(A)$ and stem bark $(B)$

value is important parameter for the determination of quality and purity of crude drugs because it is helpful for the identification of different impurities like silicate, carbonate and oxalate. The presence of inorganic compounds is determined by water soluble ash, while acid insoluble ash is used for the determination of contamination with earthy material [19].

Fluorescence is an important phenomenon displayed by various phytoconstituents of plant materials. Some show fluorescence in the visible range in daylight. The ultraviolet light produces fluorescence in many natural products, which do not visibly fluorescence in daylight. Some nonfluorescent substances may be converted into fluorescent compounds after reacting with different chemical and reagents and it is helpful in qualitative assessment of crude drugs [20]. Higher plants produce secondary metabolites in large quantity which serves as important source for the botanical pesticides, natural drugs as well as precursors for many synthetic drugs [21].

Brine shrimp (Artemia salina) lethality assay is a preliminary toxicity screening test commonly used to check the cytotoxic effect of bioactive chemicals [22]. In the present research work, methanolic root bark extract showed significant activity at higher concentration, while methanolic stem bark shows no activity. Globally, more than 415 million people are affected by diabetes mellitus and number is increasing on regular bases despite of sufficient knowledge about the management of diabetes mellitus. [23]. Blood glucose level increases in type 2 diabetes due to starch hydrolysis by pancreatic $\alpha$ - amylase and reuptake of glucose by $\alpha$-glucosidase in small intestine [24]. Enzymatic modulatory activity of methanolic extract using a-amylase inhibition assay both root and stem bark extract showed no activity.

Scanning electron microscopy is an important technique for the determination of morphological parameters. In present study scanning electron microscopy of root bark powder shows irregular shape which are not uniformly attached having many spaces. Molecules are present in the form of clumps having continuous arrangements of the molecules and have sharp edges.

Scanning electron microscopy of stem bark powder shows irregular shape having many spaces. It shows collision attachment and have net-like structures, and molecules are present in the form of clumps, having irregular shape with many spaces which indicates the large capacity of drug entrapment. Similarly, at $20 \mu \mathrm{m}$ molecules, present in round globules shape with less spaces and also showed infrared spectroscopy is useful tool for obtaining structural information about different organic compounds. Different functional groups show different peaks of absorption, so different functional groups can be readily identified [25].

Infrared spectroscopy of root bark powder showed different stretching of peaks which indicates the presence of different compounds in root bark. Stretching is observed at wavenumber 
$3269 \mathrm{~cm}^{-1}$ (-H stretching), which shows that compounds may carboxylic acid. Stretching observed at wavenumber $2117 \mathrm{~cm}^{-1} \quad(\mathrm{~N}=\mathrm{C}=\mathrm{S})$ stretching, which shows that compound may belongs to isothiocyanate class. Similarly, stretching is observed at wave number $703 \mathrm{~cm}^{-1}$ which indicates $\mathrm{C}-\mathrm{H}$ bending that shows compounds o monosubstituted benzene derivative.

Infrared spectroscopy of stem bark powder shows $1^{\text {st }}$ stretching at wave number of $3659 \mathrm{~cm}^{-}$ $1 \quad(\mathrm{O}-\mathrm{H})$ stretching, which indicates that compounds may be belongs to free alcoholic class. Stretching. is observed at $3352 \mathrm{~cm}^{-1}$ wave numbers $(\mathrm{N}-\mathrm{H})$ stretching, which indicates the compounds may be belongs to aliphatic primary amines. Strong stretching is observed at 2189 $\mathrm{cm}^{-1}$ wavenumber ( $\left.\mathrm{C} \equiv \mathrm{C}\right)$ stretching, which indicates the compounds are of alkyne class. $4^{\text {th }}$ stretching is observed at wave number $2018 \mathrm{~cm}^{-1}$ of $(\mathrm{N}=\mathrm{C}=\mathrm{S}$ stretching) which shows that compounds o isothiocyanate class. stretching is observed at $866 \mathrm{~cm}^{-1}$ wave number $(\mathrm{C}-\mathrm{H})$ bending, which indicates the compounds have 1,3-disubstituted molecules.

\section{CONCLUSION}

Capparis decidua (Forsk.) Edgew root and stem bark contain variety of bioactive compounds that have medicinal potentials and therefore need to be fully investigated for their pharmacological activities.

\section{DECLARATIONS}

\section{Acknowledgement}

We are highly thankful to the Dean Faculty of Pharmacy and Pharmaceutical Sciences, University of Karachi, Karachi, Pakistan for facilitating to conduct the research work.

\section{Conflict of interest}

No conflict of interest is associated with this work.

\section{Contribution of authors}

We declare that this work was done by the author(s) named in this article and all liabilities pertaining to claims relating to the content of this article will be borne by the authors. M Asif Wazir contributed to the collection of plant materials, extraction and microscopic analysis. Talal
Shaheer performed the physicochemical analysis, while Muhammad Iqbal Azhar originated the idea and supervised the work. Zafar Alam Mehmood helped in fluorescence analysis. Faheem Ahmad Siddique helped with FTIR, while Khizar Abbas collected, analyzed the data and performed the brine shrimp lethality assay and M. Younis Khan performed enzymatic analysis. Waqar Hussain performed scanning electron microscopy. Muhammad Imran Qadir prepared the manuscript and provided technical support throughout the project.

\section{Open Access}

This is an Open Access article that uses a funding model which does not charge readers or their institutions for access and distributed under the terms of the Creative Commons Attribution License (http://creativecommons.org/licenses/by/ 4.0) and the Budapest Open Access Initiative (http://www.budapestopenaccessinitiative.org/rea d), which permit unrestricted use, distribution, and reproduction in any medium, provided the original work is properly credited.

\section{REFERENCES}

1. Ahmad F, Khan RA, Rasheed S. Study of analgesic and anti-inflammatory activity from plant extracts of Lactuca scariola and Artemisia absinthium. Med J Islamic World Acad Sci 1992; 5(2): 111-114.

2. Kaul R. Need for afforestation in the arid zones of India. La-Yaaran 1963; 13: 30-34.

3. Ahmad VU. A new spermidine alkaloid from Capparis decidua. Heterocycles 1985; 23(12): 3015.

4. Dahot MU. Chemical evaluation of the nutritive value of flowers and fruits of Capparis decidua. J Chem Soc Pak 1993; 15: 78-78.

5. Gaind K, Juneja T. Investigation on Capparis decidua: Phytochemical study of flowers and fruits. Res Bull Punjab Univ 1970; 21: 7-71.

6. Ahmad VU and Ismail $N$. Isocodonocarpine from Capparis decidua. Phytochemistry 1989; 28(9): 24932495.

7. Rathee $S$, Rathee $P$, Rathee $D$, Rathee $D$, Kumar V. Phytochemical and pharmacological potential of kair (Capparis decidua). Int J Phytomedicine 2010; 2(1)1017.

8. Goyal R, Grewal R. The influence of teent (Capparis decidua) on human plasma triglycerides, total lipids and phospholipids. Nutr Health 2003; 17(1): 71-76.

9. Yadav $P, S$ Sarkar, and D Bhatnagar. Lipid peroxidation and antioxidant enzymes in erythrocytes and tissues in aged diabetic rats. Indian J Exp Biol 1997; 35(4): 389392.

10. Mali RG, Hundiwale JC, Sonawane RS, Patil RN, Hatapakki BC. Evaluation of Capparis decidua for Trop J Pharm Res, December 2020; 19(12): 2674 
anthelmintic and antimicrobial activities. Indian $\mathrm{J}$ Nat Prod 2004; 20(4): 10-13.

11. Trease \& Evans Pharmacognosy (15th Edn). Elsevier (A division of Reed Elsevier India Pvt. Limited); 2002.

12. WHO, Quality control methods for herbal materials. 2011. https://apps.who.int/iris/handle/10665/44479 retrived on 30.09.2020.

13. Chase $C R$, Pratt R. Fluorescence of powdered vegetable drugs with particular reference to development of a system of identification. J Am Pharm Assoc 1949; 38(6): 324-331.

14. Brain KR and Turner TD. The practical evaluation of phytopharmaceuticals. Vol. 1. Wright-Scientechnica Bristol; 1975.

15. Alves TM, Silva AF, Brandão M, Grandi TS, Smânia ED, Smânia Júnior A, Zani CL. Biological screening of Brazilian medicinal plants. Memórias do Instituto Oswaldo Cruz. 2000; 95(3): 367-373.

16. Kivçak BM, Öztürk $T$, Tansel H. Antimicrobial and cytotoxic activities of Ceratonia siliqua L. extracts. Turk J Biol 2002; 26(4): 197-200.

17. Figueiredo-González $M$, et al. $\alpha$-Glucosidase and $\alpha$ amylase inhibitors from Myrcia spp.: a stronger alternative to acarbose? J Pharm Biomed Anal 2016; 118: 322-327.

18. Choudhary $N$ and Sekhon BS. An overview of advances in the standardization of herbal drugs. Int J Pharm Sci Rev Res 2011; 2(2): 55.
19. Tatiya A, Surana S, Bhavsar S, Patil D, Patil Y. Pharmacognostic and preliminary phytochemical investigation of Eulophia herbacea Lindl. Tubers (Orchidaceae). Asian Pac J Trop Dis 2012; 2: 50-55.

20. Shailaja $V$, Banji $D$. Evaluation of standardisation parameters, pharmacognostic study, preliminary phytochemical screening and in vitro antidiabetic activity of Coccinia indica fruits as per WHO guidelines. Ind $\mathrm{J}$ Pharm Bio Res 2014; 2(3): 54.

21. Duke JA. Database of phytochemical constituents of GRAS herbs and other economic plants. CRC Press, Boca Raton, FL, USA; 1992.

22. Sufian MA and Haque MR. Cytotoxic, thrombolytic, membrane stabilizing and anti-oxidant activities of Hygrophila schulli. Bangladesh J Pharmacol 2015; 10(3): 692-696.

23. Chatterjee S, Khunti K, Davies MJ. Type 2 diabetes. Lancet Glob Health. 389(10085): 2239-2251; 2017.

24. Zhang $Y$, Wong Al, Wu JE, Karim NB, Huang D. Lepisanthes alata (Malay cherry) leaves are potent inhibitors of starch hydrolases due to proanthocyanidins with high degree of polymerization. J Funct Foods 2016; 25: 568-578.

25. Rockley MG. Fourier-transformed infrared photoacoustic spectroscopy of solids. Appl Spectrosc 1980; 34(4): 405-406. 